\title{
Callus formation and somatic embryogenesis in sugarcane (Saccharum spp L.) using various concentrations of 2 , 4-D and RAPD analysis of regenerated plants
}

Misbah Naz ${ }^{1,2 *}$ and Faisal Hayat ${ }^{3}$

1. College of Resources and Environmental Science, State Key Laboratory of Crop Genetics and Germplasm Enhancement,Nanjing Agriculture University 210095, P.R , Nanjing-China

2. Nuclear Institute of Agriculture, Tando Jam-Pakistan

3. College of Horticulture, China Agricultural University, Beijing 100083-Prchina-China

*Corresponding author's email: raymisbah@ymail.com

Citation

Misbah Naz and Faisal Hayat. Callus formation and somatic embryogenesis in sugarcane (Saccharum spp L.) using various concentrations of 2, 4-D and RAPD analysis of regenerated plants. Pure and Applied Biology. Vol. 6, Issue 3, pp917-931. http://dx.doi.org/10.19045/bspab.2017.60097

\begin{tabular}{llll}
\hline \hline Received: $15 / 02 / 2017$ & Revised: $23 / 06 / 2017$ & Accepted: $18 / 07 / 2017$ & Online First: 22/07/2017 \\
\hline \hline
\end{tabular}

\section{Abstract}

The present study was carried out to build up an efficient protocol for various concentrations of 2, 4D for "Callus formation and somatic embryogenesis in sugarcane (Saccharum spp L.) using various concentrations of 2, 4-D and RAPD analysis of regenerated plants in the laboratory of Biotechnology Nuclear Institute of Agriculture, Tandojam during the year 2015 to 2016. Three sugarcane varieties B14, NIA-2010, NIA-2011 with different concentrations of 2, 4-D (0.5.1.0, 2.0, 3.0 and 4.0 mg L-1) were used respectively, while $3.0 \mathrm{mg} \mathrm{L}^{-1} \mathrm{Kin}+\mathrm{IAA}+\mathrm{IBA}$ was used for callus proliferation and shoot formations. Four different concentration of IBA were used for rooting purposes 0.5, 1.0, 2.0 and 3.0 $\mathrm{mgL}^{-1}+20 \mathrm{~g}$ Sugar. Embryogenic callus was obtained by culturing young apical meristem. Three sugarcane clones BL4, NIA-2010 and NIA-2 011 were developed in the field area for eight month and sand was used for tissue culture somatic embryonic callus study. Apical meristematic region was used for callus formation and somatic embryogenesis induction on $0.5,1.0,2.0,3.0$ and $4.0 \mathrm{mg} \mathrm{L}^{-1} .2$, 4-D actively growing callus was subcultured on kin. IAA, IBA, $3.0 \mathrm{mg} \mathrm{L}^{-1}$. Maximum callus proliferation and number of plantlets shoot length and regeneration growth were observed in plants that 1.0 and $2.0 \mathrm{mg} \mathrm{L}^{-1} 2,4$-D callus was taken from. Maximum chlorophyll mutation frequency was observed in NIA-2010 and BL4 grown on $1.0 \mathrm{mg} \mathrm{L}^{-1}$ 2, 4-D. Maximum number of roots were observed in BL4 when $1.0 \mathrm{mg} \mathrm{L}^{-1} \mathrm{IBA}+20 \%$ sugar was applied; variability was also obtained through callus culture and confirmed through random amplified polymorphic DNA (RAPD) techniques.

Keywords: Embryonic callus induction; Callus proliferation; Chlorophyll mutant regeneration and root formation

Introduction

Sugarcane (Saccharum spp L.) hybrid is a profitable crop cultivated in 74 countries around the globe [1]. It is a perennial crop 
and belongs to Poaceae family, which contributes approximately $75 \%$ of worldwide sugar production [2]. Other than sucrose production, it is likewise utilized as part of Ayurvedic drugs and for the treatment of skin and urinary tract diseases, bronchitis, heart conditions, loss of milk production, cough, anemia, constipation and also general debility [3]. Another essential utilization of sugarcane is the production of press mud, which is utilized as a source of organic matter and supplements for crop production [4].

Sugarcane is the world largest crop by production, the annual production of sugarcane in the world is 1.83 billion tons having an area of 26.1 million hectares. The average yield of sugarcane in the world is 70.24 tons/ha. Pakistan produces 58.4 million tons by harvesting 1.04 million hectare and the yield is 55.8 tons/ha [5]. In Pakistan, sugarcane is the biggest industrial cash crop second to cotton and is basic as a result of its huge share in agriculture sector. Various demands for sugarcane in agricultural industry has vitalized the need for continuous varietal improvement and extensive research on the crop [6] An extensive breeding work, management and cultural practices are required to narrow down this big gap. Although, a good crop is harvested in Pakistan, it does not flower and produce seed (fuzz) under normal growing conditions in the country.

Non-sporadic flowering and natural viable and fertile seed production has usually been a problem in Pakistan. Modern sugarcane varieties have multifarious genetic characteristics and low fertility that renders their genetic improvement is very difficult through traditional breeding. Thus the substitute method for propagation is in vitro culture techniques and induced transformation being utilized to make the new genetic variability for the determination of desired clones of sugarcane [7]. In-vitro culture technique is enriched with high cane yield, resistance to biotic and a biotic stresses. Callus culture of sugarcane has been efficiently settled utilizing shoot apices, young leaves and young inflorescences as explants.

Sugar yield of Pakistan is small as compared to other countries of the world and genetic improvement through customary hybridization in Pakistan is hampered due to the complex flowering nature of sugarcane [8]. The genetic variability created through traditional breeding techniques is slow and depends on recombination [9]. In conventional breeding method, development of selected sugarcane cultivars with high sugar yield and disease resistance is often defeated by tight linkage between cane quality, cane yield and disease resistance etc. The developments in plant tissue culture have opened up new possibilities in creating genetic variability. Somatic embryogenesis is a common regeneration pathway which is being stated by many scientists $[7,10,11]$. Plant tissue culture is the best technique through callusing of sugarcane for variation, genetic advancement, quality and phytosanitary planting material at a speedier rate in a smaller duration of time. Callus prompting was seen few weeks after explants under proper condition and the differentiation of either shoots from callus of sugarcane assortments easily acquired [12] Leaf sheath were utilized as explants to induce callus on modified MS supplemented with various concentrations of 2, 4-D as growth regulators [13].

The major area of utilization of tissue culture in sugarcane improvement are for the production of somaclones through callus culture for disease resistance [14] and variety in plant morphology due to 
dissimilarity in chromosome number [15]. These studies uncover that the effective use of tissue culture technology for the improvement of sugarcane is subject to the capacity to start, keep up and control and regenerate plants from callus [16] The genetic variability through conventional breeding techniques is slow and depends on recombination [17]. The achievements in plant tissue culture have opened up new possibilities in creating genetic variability. Auxin is reflected to be the most essential hormone in managing somatic embryogenesis [10]. Different biotechnological techniques are used to modify the existing plant characteristics or to generate new ones. For this purpose, plant tissue culture techniques, predominately somatic embryogenesis are being practiced.

Somatic embryogenesis is well renowned and most famous method to produce numerous plantlets from callus in limited time span. Somatic embryoids induced on embryogenic callus regenerate into several numbers of plantlets. The plants regenerated from somatic embryoids are indistinguishable in all genetic and agronomic characteristics in light of single cell [6] Molecular markers are the most efficient tool to evaluate genetic reliability of the regenerated plantlets. This could be a down to earth way to deal with screen somaclonal variations created in tissue cultured plants, for example, in sugarcane [12] PCR based molecular markers, such as RAPD technique most often is being utilized for assessment of somaclonal variation and estimation of genetic fidelity DNA investigation in sugarcane embryogenesis regenerated plants [18].
Optimized conditions for callus induction in sugarcane have been studied investigated in the present study. This optimized protocol will help in establishing efficient method for the genetic transformation in callus of the important sugarcane varieties for resistance to various stresses. Present study was conducted to induce the callus and somatic embryogenesis in different genotypes of sugarcane (BL4, NIA-2010 and NIA-2011) with the use of different concentrations of 2 , 4-D (0.5, 1.0, 2.0, 3.0 and $\left.4.0 \mathrm{mg} \mathrm{L}^{-1}\right)$. Embryonic calliis then regenerated and analyzed through DNA RAPD marker for genomic variations among the somaclones and its mother plant.

\section{Materials and methods}

The research was carried out at Nuclear Institute of Agriculture,Tandojam for callus formation and somatic embryogenesis in sugarcane (Saccharum sppL.) using various concentrations of 2, 4-D and RAPD investigation of regenerated plants of BL4, NIA-2010 and NIA-2011. Laboratory used was well equipped and facilitated by culture and washing room, laminar airflow cabinet, culture vessels, incubation room, autoclave, $\mathrm{pH}$ meter, electric oven, glass house, centrifuge machine, spectrophotometer, PCR and Gel documentation and miscellaneous needs.

Preparation of micronutrient stock solution

The quantities each of salts (Table 1) were measured and transferred into the conical flask and sterilized ( $\mathrm{ddH} 2 \mathrm{O})$, distilled water $700 \mathrm{ml}$ was then delivered into conical flask. Solution was stirred to dissolve properly and transferred to volumetric flask (1L) and made up to volume. The flask was labeled and stored in the refrigerator. 
Table1. Preparation of MS basal medium, first discovered by Murashige, T; Skoog, F (1962). [19]

\begin{tabular}{|l|l|c|}
\hline Ingredient & Chemical composition & Weight in mg/L \\
\hline Micronutrients & & \\
\hline Manganese sulphate & MnSO4 .4H2 O & 22.2 \\
\hline Zine sulphate & ZnSO4 .7H2 O & 8.2 \\
\hline Boric acid & $\mathrm{H} 3 \mathrm{BO} 3$ & 6.2 \\
\hline Potassium lodide & $\mathrm{K} 1$ & 0.83 \\
\hline Sodium molybdate & $\mathrm{Na} 2 \mathrm{MoO} 4.2 \mathrm{H} 2 \mathrm{OHH}$ & 0.025 \\
\hline Copper sulphate & $\mathrm{CuSO} 4.5 \mathrm{H} 2 \mathrm{O}$ & 0.025 \\
\hline Cobalt chloride & $\mathrm{CoCl} 2.6 \mathrm{H} 2 \mathrm{O}$ & 0.025 \\
\hline Iron & & 27.8 \\
\hline Iron sulphate & $\mathrm{FeSO} 4.5 \mathrm{H} 2 \mathrm{O}$ & 37.26 \\
\hline $\begin{array}{l}\text { Sodium EDTA (Sodium } \\
\text { diamine tetra acetic acid) }\end{array}$ & $\mathrm{Na} 2 \mathrm{ETDA} .2 \mathrm{H} 2 \mathrm{O}$ & \\
\hline Vitamins & & 0.5 \\
\hline Thiamine HCI & & $0.1 \mathrm{~g} / 1$ \\
\hline Myo-inosital & $\mathrm{C} 12 \mathrm{H} 8 \mathrm{~N} 4 \mathrm{OSCl} 2$ & \\
\hline Macronutrients & & $1.09 \mathrm{~g} / 1$ \\
\hline Potassium nitrate & & $1.65 \mathrm{~g} / 1$ \\
\hline Ammonium nitrate & $\mathrm{KNO} 3$ & $0.44 \mathrm{~g} / 1$ \\
\hline Calcium chloride & $\mathrm{NH} 4 \mathrm{NO} 3$ & $0.17 \mathrm{~g} / 1$ \\
\hline Potassium phosphate & $\mathrm{CaCl} 2.2 \mathrm{H} 20$ & $0.37 \mathrm{~g} / 1$ \\
\hline Magnesium sulphate & $\mathrm{KH} 2 . \mathrm{PO} 4$ & $25.00 \mathrm{~g} / 1$ \\
\hline Sugar & $\mathrm{MgSO} 4.7 \mathrm{H} 20$ & $2.00 \mathrm{~g} / 1$ \\
\hline Casein & $\mathrm{C} 12 \mathrm{H} 22 \mathrm{O} 11$ & $8.00 \mathrm{~g} / 1$ \\
\hline AGAR & &
\end{tabular}

Preparation of vitamin based stock solution

The quantities of ingredients for the vitamin stock presented (Table 1) were measured into conical flask having some quantity of sterilized distilled water and mixed thoroughly using magnetic stirrer. The solution was transferred into volumetric flask 11 and made up to volume and the flask labeled and stored in refrigerator till use. The following are the growth regulators stock solution for somatic embryogenesis callus formation shoot regeneration and rooting forming culture media: a) 2, 4Dichloro phenoxy acetic acid; b) Kinetin; c) Indol-3- acetic acid and d) IBA Indole-3butyric acid.

\section{Preparation of laminar air flow cabinet}

The laminar air flow cabinet was switched on for $30 \mathrm{~min}$.

Before starting the process of culturing, it was uncontaminated with absolute alcohol like $70 \%$ ethanol. After laminar air flow cabinet was further sterilized with all required materials and kept inside the cabinet.

\section{Selection of explants, surface sterilization} and culture

Ten (10) explants containing apical meristems were taken from every genotype. Superfluous part of cane top was uprooted and the remaining initially washed with refined water and afterward disinfected with 
70\% Alcohol (ethanol) for 1 min and 20\% sodium hypochloride solution for $20 \mathrm{~min}$. After sanitization explants material were washed with double refined water 2 to 3 times to uproot any hints of disinfectant under aseptic conditions in laminar air flow cabinet. These sterilized meristem or shoot tip was cut or isolated from stem and a Vshaped cut with sterilized knife applied. In the meristem tip culture, the cut was a small piece applied 0.3 to $0.5 \mathrm{~mm}$ below the tip of the dome and the excised tissue (explants) was removed along portion of procambial tissue and immediately planted on media.

Molecular marker RAPD analysis of somatic embryo-derived plants among mother plants

RAPD is any DNA Segment that is amplified using short oligodeoxy nucleotide primers of arbitrary nucleotide sequence and polymerase chain reaction procedure.

\section{Buffer solution genomic DNA extraction}

Total genomic DNA was separated from samples of young leaf tissue of all the three varieties B14, NIA-2010, NIA-2011; three specimens of that recovered from somatic embryo callus were taken from field plantlets' and determined through nodal shoot multiplication and somatic embryogenesis from every accession. Leaf tissues were ground into fine powder in liquid nitrogen using a mortar and pestle. Buffer chemicals for 500X reactions used are: $50 \mathrm{ml}$ Tris- $\mathrm{HCl}, 140 \mathrm{ml}$ MATAB, $20 \mathrm{ml}$ EDTA, $10 \mathrm{~g} \mathrm{NaCl}, 5 \mathrm{~g}$ PEG 6000 and $2.5 \mathrm{~g}$ $\mathrm{Na} 2 \mathrm{SO} 3$ (Table 2).

Table 2. Buffer chemicals

\begin{tabular}{|l|l|}
\hline Chemicals & For 500X reactions \\
\hline Tris-HCl & $50 \mathrm{ml}$ \\
\hline MATAB & $140 \mathrm{ml}$ \\
\hline EDTA & $20 \mathrm{ml}$ \\
\hline NaCl & $10 \mathrm{~g}$ \\
\hline PEG 6000 & $5 \mathrm{~g}$ \\
\hline Na2SO3 & $2.5 \mathrm{~g}$ \\
\hline
\end{tabular}

Random amplified polymorphic DNA (RAPD) analysis of plants regenerated from embryogeniccalli

Deoxyribonucleic acid (DNA) was extracted using the protocol of $[12,20]$. Sample for DNA extraction were the control, which is propagated through sets and seven randomly selected somaclones of BL4, NIA-210 and NIA-2011.Genomic DNA was quantified spectrometrically. Polymerase chain reaction (PCR) amplification was done using RAPD primers (Operon Technologies, Alameda, USA). Four (4) operon primers were selected for the study. The selected primers A2, A3, A8, A10 PCR was performed in 15 $\mathrm{ml}$ reaction. $12 \mathrm{ng}$ of the template DNA was amplified with one unit of taq DNA polymerase $(0.1 \mu \mathrm{l})$ in a $15 \mu \mathrm{l}$ reaction mixture containing $10 \times$ PCR buffer $(1.5 \mu l)$, $0.2 \mathrm{mM}$ of dNTPs $(0.33 \mu \mathrm{M})$ and $1 \mu \mathrm{M}$ of random primer. Amplification was performed in a BioRad PTC 200 Thermal Cycler System and initiated by a denaturation of $3 \mathrm{~min}$ at $95^{\circ} \mathrm{C}$ followed by 40 cycles of $94^{\circ} \mathrm{C}$ for $1 \mathrm{~min}, 37^{\circ} \mathrm{C}$ for $1 \mathrm{~min}$, $72^{\circ} \mathrm{C}$ for $2 \mathrm{~min}$. The amplification was completed with 1 cycle of $7 \mathrm{~min}$ at $72^{\circ} \mathrm{C}$.

\section{Results and discussion}

The results on weight of explants/bottle, weight of Callus/bottle, weight of proliferation /bottle, type of callus, number of shoots per bottle, shoot length per bottle, 
number of chlorophyll mutants per bottle and number of roots of sugarcane callus induction under various concentrations of 2 ,
4-D recorded are presented in Tables 1, 3 to 8 and their analysis of variance and data shown in Table 9.

Table 3. Analysis of variance weight of somatic callus in the various concentration of 2, 4-D with different varieties

\begin{tabular}{|c|c|c|c|c|c|}
\hline $\begin{array}{l}\text { Concentrations of } 2,4- \\
\text { D mgl }{ }^{-1}\end{array}$ & BL4 & NIA-2010 & \multicolumn{2}{|c|}{ NIA-2011 } & Mean \\
\hline 0.5 & $0.79^{b-d}$ & $0.84^{\mathrm{bc}}$ & \multicolumn{2}{|c|}{$0.57^{\mathrm{ce}}$} & $0.73^{\mathrm{bc}}$ \\
\hline 1.0 & $0.95^{\mathrm{b}}$ & $0.45^{\mathrm{de}}$ & \multicolumn{2}{|c|}{$1.38^{\mathrm{a}}$} & $0.92^{\mathrm{ab}}$ \\
\hline 2.0 & $0.86^{\mathrm{bc}}$ & $0.40^{\mathrm{e}}$ & \multicolumn{2}{|c|}{$1.65^{\mathrm{a}}$} & $0.97^{\mathrm{a}}$ \\
\hline 3.0 & $0.38^{\mathrm{e}}$ & $0.55^{\mathrm{ce}}$ & \multicolumn{2}{|c|}{$0.84^{\mathrm{bc}}$} & $0.59^{\text {cd }}$ \\
\hline 4.0 & $0.82^{b-d}$ & $0.36^{\mathrm{e}}$ & \multirow{2}{*}{\multicolumn{2}{|c|}{$\frac{0.24^{\mathrm{e}}}{0.93^{\mathrm{a}}}$}} & $0.47^{\mathrm{d}}$ \\
\hline Mean & $0.76^{\mathrm{a}}$ & $0.52^{\mathrm{c}}$ & & & \\
\hline Source & $\begin{array}{l}\text { Degrees of } \\
\text { freedom }\end{array}$ & $\begin{array}{l}\text { Sum of } \\
\text { squares }\end{array}$ & F value & $\mathbf{P}$ & Remark \\
\hline Rep & 5 & 0.5457 & - & - & - \\
\hline Varieties & 2 & 2.1703 & 12.44 & 0.0000 & \\
\hline Treat & 4 & 2.7215 & 7.80 & 0.0000 & $* *$ \\
\hline Varieties*Treat & 8 & 5.6749 & 8.13 & 0.0000 & ** \\
\hline Error & 56 & 4.8845 & - & - & - \\
\hline Total & 74 & 15.9969 & - & - & - \\
\hline
\end{tabular}

Table 4. Effect of different growth regulator concentrations of 2, 4-D on callus induction of sugarcane somaclones

\begin{tabular}{|c|c|}
\hline Growth regulator concentration & Type of callus \\
\hline \multicolumn{2}{|l|}{ BL4 } \\
\hline $2,4-\mathrm{D}\left(0.5 \mathrm{mg} \mathrm{L}^{-1}\right)$ & Nodular Compact (A) \\
\hline 2,4-D $\left(1.0 \mathrm{mg} \mathrm{L}^{-1}\right)$ & Nodular Compact (A) \\
\hline $2,4-\mathrm{D}\left(2.0 \mathrm{mg} \mathrm{L}^{-1}\right)$ & Nodular Compact (A) \\
\hline $2,4-\mathrm{D}\left(3.0 \mathrm{mg} \mathrm{L}^{-1}\right)$ & Nodular Compact (A) \\
\hline $2,4-\mathrm{D}\left(4.0 \mathrm{mg} \mathrm{L}^{-1}\right)$ & Nodular Compact (A) \\
\hline \multicolumn{2}{|l|}{ NIA-2010 } \\
\hline $2,4-\mathrm{D}\left(0.5 \mathrm{mg} \mathrm{L}^{-1}\right)$ & Nodular Compact /smooth Compact (A and B) \\
\hline $2,4-\mathrm{D}\left(1.0 \mathrm{mg} \mathrm{L}^{-1}\right)$ & Nodular Compact /smooth Compact (A and B) \\
\hline $2,4-\mathrm{D}\left(2.0 \mathrm{mg} \mathrm{L}^{-1}\right)$ & Nodular Compact (A) \\
\hline $2,4-\mathrm{D}\left(3.0 \mathrm{mg} \mathrm{L}^{-1}\right)$ & Nodular Compact (A) \\
\hline $2,4-\mathrm{D}\left(4.0 \mathrm{mg} \mathrm{L}^{-1}\right)$ & Nodular Compact (A) \\
\hline \multicolumn{2}{|l|}{ NIA-2011 } \\
\hline $2,4-\mathrm{D}\left(0.5 \mathrm{mg} \mathrm{L}^{-1}\right)$ & Nodular/smooth Compact (A and B) \\
\hline $2,4-\mathrm{D}\left(1.0 \mathrm{mg} \mathrm{L}^{-1}\right)$ & Nodular/smooth Compact (A and B) \\
\hline 2,4-D $\left(2.0 \mathrm{mg} \mathrm{L}^{-1}\right)$ & Nodular/smooth Compact (A and B) \\
\hline $2,4-\mathrm{D}\left(3.0 \mathrm{mg} \mathrm{L}^{-1}\right)$ & Nodular/smooth Compact (A and B) \\
\hline $2,4-\mathrm{D}\left(4.0 \mathrm{mg} \mathrm{L}^{-1}\right)$ & Nodular/smooth Compact (A and B) \\
\hline
\end{tabular}


Table 5. Analysis of variance weight of somatic callus proliferation in the various concentration of $2,4-D$ with different varieties

\begin{tabular}{|l|c|c|c|c|}
\hline $\begin{array}{l}\text { Concentrations of 2,4-D } \\
\text { mgL-1 }\end{array}$ & BL4 & NIA-2010 & NIA-2011 & Mean \\
\hline 0.5 & $1.43^{\mathrm{d}}$ & $1.10^{\mathrm{de}}$ & $1.25^{\mathrm{de}}$ & $1.26^{\mathrm{b}}$ \\
\hline 1.0 & $1.07 \mathrm{~d}^{\mathrm{e}}$ & $0.95^{\text {ef }}$ & $2.45^{\mathrm{a}}$ & $1.49^{\mathrm{ab}}$ \\
\hline 2.0 & $1.21^{\mathrm{de}}$ & $0.89^{\mathrm{ef}}$ & $2.06^{\mathrm{ab}}$ & $1.39^{\mathrm{ab}}$ \\
\hline 3.0 & $1.94^{\mathrm{bc}}$ & $1.53^{\mathrm{cd}}$ & $1.49^{\mathrm{cd}}$ & $1.65^{\mathrm{a}}$ \\
\hline 4.0 & $0.83^{\mathrm{ef}}$ & $0.52^{\mathrm{fg}}$ & $0.33^{\mathrm{g}}$ & $0.56^{\mathrm{c}}$ \\
\hline Mean & $1.29^{\mathrm{b}}$ & $1.00^{\mathrm{c}}$ & $1.52^{\mathrm{a}}$ & \\
\hline
\end{tabular}

Analysis of variance for weight of callus proliferation/bottle

\begin{tabular}{|l|c|c|c|c|c|c|}
\hline Source & $\begin{array}{l}\text { Degrees of } \\
\text { freedom }\end{array}$ & $\begin{array}{l}\text { Sum of } \\
\text { squares }\end{array}$ & $\begin{array}{l}\text { Mean } \\
\text { square }\end{array}$ & F-value & $\mathbf{P}$ & Remark \\
\hline Rep & 5 & 0.1269 & 0.03172 & - & - & - \\
\hline Varieties & 2 & 3.4224 & 1.71122 & 12.09 & 0.0000 & $* *$ \\
\hline Treat & 4 & 10.7018 & 2.67546 & 18.91 & 0.0000 & $* *$ \\
\hline Varieties*Treat & 8 & 8.7704 & 1.09630 & 7.75 & 0.0000 & $* *$ \\
\hline Error & 56 & 7.9239 & 0.14150 & - & - & - \\
\hline Total & 74 & 30.9454 & - & - & - & - \\
\hline
\end{tabular}

Table 6. Analysis of variance number of plants /bottle that regenerated from in the various concentration of $2,4-D$ with different varieties

\begin{tabular}{|c|c|c|c|c|c|}
\hline $\begin{array}{l}\text { Concentrations of 2,4-D } \\
\text { mgL }^{-1}\end{array}$ & B14 & 2010 & 2011 & \multicolumn{2}{|l|}{ Mean } \\
\hline 0.5 & $22.000^{f}$ & $20.000^{\mathrm{g}}$ & $16.000^{\mathrm{i}}$ & \multicolumn{2}{|c|}{$19.333^{\mathrm{d}}$} \\
\hline 1.0 & $30.000^{\mathrm{c}}$ & $22.000^{\mathrm{f}}$ & $21.000^{\mathrm{fg}}$ & \multicolumn{2}{|c|}{$24.333^{\mathrm{c}}$} \\
\hline 2.0 & $30.000^{c}$ & $33.400^{\mathrm{a}}$ & $22.000^{\mathrm{f}}$ & \multicolumn{2}{|c|}{$28.467^{\mathrm{a}}$} \\
\hline 3.0 & $25.200^{\mathrm{d}}$ & $31.800^{\mathrm{b}}$ & $21.800^{\mathrm{f}}$ & \multicolumn{2}{|c|}{$26.267^{\mathrm{b}}$} \\
\hline 4.0 & $24.000^{\mathrm{e}}$ & $30.000^{\mathrm{c}}$ & $17.600^{\mathrm{h}}$ & \multicolumn{2}{|c|}{$23.867^{\mathrm{c}}$} \\
\hline Mean & $26.24^{\mathrm{b}}$ & $27.44^{\mathrm{a}}$ & $19.68^{\mathrm{c}}$ & & \\
\hline \multicolumn{6}{|c|}{ Analysis of variance for number of plants / bottle } \\
\hline Source & $\begin{array}{c}\begin{array}{c}\text { Degrees of } \\
\text { freedom }\end{array} \\
\end{array}$ & $\begin{array}{l}\text { Sum of } \\
\text { squares }\end{array}$ & $\begin{array}{l}\text { Mean } \\
\text { square }\end{array}$ & $\mathbf{P}$ & Remark \\
\hline Rep & 5 & 153.12 & 38.28 & - & - \\
\hline Treat & 4 & 689.52 & 172.38 & 0 & $* *$ \\
\hline Varieties & 2 & 872.43 & 436.213 & 0 & $* *$ \\
\hline Treat*Varieties & 8 & 449.84 & 56.23 & 0 & $* *$ \\
\hline Error & 56 & 37.68 & 0.673 & - & - \\
\hline Total & 74 & 2202.59 & - & - & - \\
\hline
\end{tabular}


Table 7. Analysis of variance Size of shoot length plant-1that regenerated from in the various concentration of $2,4-D$ with different varieties

\begin{tabular}{|c|c|c|c|c|c|c|}
\hline \multirow{2}{*}{$\begin{array}{l}\text { Concentration } \\
\text { s of } 2,4-D \mathrm{mgL}^{-} \\
1\end{array}$} & $\begin{array}{c}\text { BL4 Shoots } \\
\text { length }\end{array}$ & \multicolumn{2}{|c|}{$\begin{array}{l}\text { NIA-2010 shoots } \\
\text { length plant }^{-1}\end{array}$} & \multicolumn{2}{|c|}{$\begin{array}{c}\text { NIA-2011 shoots } \\
\text { length }\end{array}$} & \multirow[t]{2}{*}{ Mean } \\
\hline & plant $^{-1}(\mathrm{c})$ & \multicolumn{2}{|c|}{ (c) } & \multicolumn{2}{|c|}{ plant $^{-1}(\mathrm{c})$} & \\
\hline 0.5 & $2.60^{\mathrm{fg}}$ & \multicolumn{2}{|l|}{$2.00^{\mathrm{g}}$} & \multicolumn{2}{|c|}{$1.60^{\mathrm{g}}$} & $2.06 \mathrm{e}$ \\
\hline 1 & $9.20^{\mathrm{a}}$ & \multicolumn{2}{|l|}{$8.00^{\mathrm{ab}}$} & \multicolumn{2}{|l|}{$3.80^{\mathrm{ef}}$} & $7.00^{\mathrm{a}}$ \\
\hline 2 & $6.80^{\mathrm{bc}}$ & \multicolumn{2}{|l|}{$6.00^{\mathrm{cd}}$} & \multicolumn{2}{|l|}{$4.00^{\mathrm{ef}}$} & $5.60^{\mathrm{b}}$ \\
\hline 3 & $7.20^{\mathrm{bc}}$ & \multicolumn{2}{|l|}{$4.00^{\mathrm{ef}}$} & \multicolumn{2}{|l|}{$2.80^{\mathrm{fg}}$} & $4.66^{\mathrm{c}}$ \\
\hline 4 & $5.00^{\mathrm{de}}$ & \multicolumn{2}{|l|}{$2.60^{\mathrm{fg}}$} & \multicolumn{2}{|l|}{$3.00^{\mathrm{fg}}$} & $3.53^{\mathrm{d}}$ \\
\hline Mean & $6.16^{\mathrm{a}}$ & \multicolumn{2}{|c|}{$4.52^{\mathrm{b}}$} & \multicolumn{2}{|l|}{$2.36^{\mathrm{c}}$} & \\
\hline \multicolumn{7}{|c|}{ Analysis of variance for number of shoot / plantlets } \\
\hline Source & $\begin{array}{l}\text { Degrees of } \\
\text { freedom }\end{array}$ & $\begin{array}{l}\text { Sum of } \\
\text { squares }\end{array}$ & $\begin{array}{l}\text { Mean } \\
\text { square }\end{array}$ & F-value & $\mathbf{P}$ & Remark \\
\hline Rep & 5 & 36.613 & 9.1533 & - & - & - \\
\hline Varieties & 2 & 121.787 & 60.8933 & 46.72 & 0.0000 & $* *$ \\
\hline Treat & 4 & 214.747 & 53.6867 & 41.19 & 0.0000 & $* *$ \\
\hline Varieties*Treat & 8 & 50.213 & 6.2767 & 4.82 & 0.0002 & $* *$ \\
\hline Error & 56 & 72.987 & 1.3033 & - & - & - \\
\hline Total & 74 & 496.347 & - & - & - & - \\
\hline
\end{tabular}

Table 8. Analysis of variance number of chlorophyll mutant /bottle that regenerated from in the various concentrations of 2, 4-D on kinetin, IBA, IAA $3.0 \mathrm{mg}$ l-1 concentrations with different varieties

\begin{tabular}{|c|c|c|c|c|c|c|}
\hline $\begin{array}{l}\text { Concentrations } \\
\text { of } 2,4-D \mathrm{mgL}^{-1}\end{array}$ & BL4 & \multicolumn{2}{|l|}{ NIA-2010 } & \multicolumn{2}{|c|}{ NIA-2011 } & Mean \\
\hline 0.5 & $1.60^{c-e}$ & \multicolumn{2}{|l|}{$1.20^{\mathrm{de}}$} & \multicolumn{2}{|l|}{$1.00^{\mathrm{e}}$} & $1.26^{\mathrm{c}}$ \\
\hline 1.0 & $6.00^{\mathrm{a}}$ & \multicolumn{2}{|l|}{$6.40^{\mathrm{a}}$} & \multicolumn{2}{|l|}{$2.80^{\mathrm{bc}}$} & $5.06^{\mathrm{a}}$ \\
\hline 2.0 & $3.00^{\mathrm{bc}}$ & \multicolumn{2}{|l|}{$5.40^{\mathrm{a}}$} & \multicolumn{2}{|l|}{$2.20^{\mathrm{b}-\mathrm{e}}$} & $3.53^{b}$ \\
\hline 3.0 & $3.60^{\mathrm{b}}$ & \multicolumn{2}{|l|}{$2.60^{\mathrm{b}-\mathrm{d}}$} & \multicolumn{2}{|l|}{$3.20^{b}$} & $3.13^{b}$ \\
\hline 4.0 & $2.60^{b-d}$ & \multicolumn{2}{|l|}{$3.00^{\mathrm{bc}}$} & \multicolumn{2}{|l|}{$2.60^{\mathrm{b}-\mathrm{d}}$} & $2.73^{b}$ \\
\hline Mean & $3.36^{\mathrm{b}}$ & \multicolumn{2}{|l|}{$3.72^{\mathrm{a}}$} & \multicolumn{2}{|l|}{$2.36^{\mathrm{c}}$} & \\
\hline \multicolumn{7}{|c|}{ Analysis of variance for chlorophyll mutant/bottle } \\
\hline Source & $\begin{array}{l}\text { Degrees of } \\
\text { freedom }\end{array}$ & $\begin{array}{l}\text { Sum of } \\
\text { squares }\end{array}$ & $\begin{array}{l}\text { Mean } \\
\text { square }\end{array}$ & F value & $\mathbf{P}$ & Remark \\
\hline Rep & 5 & 4.187 & 1.0467 & - & - & - \\
\hline Varieties & 2 & 24.827 & 12.4133 & 8.75 & 0.0005 & $* *$ \\
\hline Treat & 4 & 113.120 & 28.2800 & 19.94 & 0.0000 & $* *$ \\
\hline Varieties*Treat & 8 & 45.840 & 5.7300 & 4.04 & 0.0008 & $* *$ \\
\hline Error & 56 & 79.413 & 1.4181 & - & - & - \\
\hline Total & 74 & 267.387 & & - & - & - \\
\hline
\end{tabular}


Table 9.Genetic polymorphism among the different varieties of sugarcane sequence of the primers

\begin{tabular}{|l|l|}
\hline Primer code & Sequence (5' $\mathbf{- 3}^{\prime}$ ) \\
\hline A2 & TGACCGAGCTG \\
\hline A3 & AGTCAGCCAC \\
\hline A8 & GTGACGTAGG \\
\hline A10 & GTGATCGCAG \\
\hline
\end{tabular}

Weight of explants /bottle (g)

Statistical analysis of variances was found significantly different at $5 \%$ probability level. The maximum weight of explants in clone BL4, however, no significant difference was observed in weight of explants variety and treatment (Table 10).

Table 10. Weight of explants per bottle $(\mathrm{g})$

\begin{tabular}{|l|l|l|l|l|}
\hline $\begin{array}{l}\text { Concentrations } \\
\text { of 2,4-D mg-1 }\end{array}$ & BI4 & NIA-2010 & NIA-2011 & Mean \\
\hline 0.5 & $0.84^{\mathrm{ab}}$ & $0.35^{\mathrm{ef}}$ & $0.44^{\mathrm{d}-\mathrm{f}}$ & $0.54^{\mathrm{ab}}$ \\
\hline 1.0 & $0.92^{\mathrm{a}}$ & $0.36^{\mathrm{ef}}$ & $0.73 \mathrm{a}-\mathrm{c}$ & $0.67^{\mathrm{a}}$ \\
\hline 2.0 & $0.91^{\mathrm{a}}$ & $0.37^{\mathrm{ef}}$ & $0.67^{\mathrm{a}-\mathrm{d}}$ & $0.65^{\mathrm{a}}$ \\
\hline 3.0 & $0.32^{\mathrm{f}}$ & $0.47^{\mathrm{c}-\mathrm{f}}$ & $0.49^{\mathrm{c}-\mathrm{f}}$ & $0.43^{\mathrm{b}}$ \\
\hline 4.0 & $0.73^{\mathrm{a}-\mathrm{c}}$ & $0.56^{\mathrm{b}-\mathrm{f}}$ & $0.62^{\mathrm{b}-\mathrm{e}}$ & $0.64^{\mathrm{a}}$ \\
\hline Mean & $0.74^{\mathrm{a}}$ & $0.42^{\mathrm{c}}$ & $0.59^{\mathrm{b}}$ & \\
\hline Analysis & & & \\
\hline
\end{tabular}

\section{Analysis of variance for weight of explants/bottle}

\begin{tabular}{|l|c|l|l|c|c|c|}
\hline Source & $\begin{array}{c}\text { Degrees of } \\
\text { freedom }\end{array}$ & $\begin{array}{l}\text { Sum of } \\
\text { squares }\end{array}$ & $\begin{array}{l}\text { Mean } \\
\text { square }\end{array}$ & F-value & P & Remark \\
\hline Rep & 5 & 0.36977 & 0.09244 & - & - & - \\
\hline Varieties & 2 & 1.28376 & 0.64188 & 12.67 & 0.0000 & $* *$ \\
\hline Treat & 4 & 0.60018 & 0.15005 & 2.96 & 0.0273 & $*$ \\
\hline V $\times \mathrm{T}$ & 8 & 1.06325 & $0.13291 \mathrm{~ns}$ & 2.62 & 0.0163 & $\mathrm{~ns}$ \\
\hline Error & 56 & 2.83643 & 0.05065 & - & - & - \\
\hline Total & 74 & 6.15339 & - & - & - & - \\
\hline
\end{tabular}

\section{Weight of callus / bottle (g)}

The concentrations of 2,4-D 1.0 and $2.0 \mathrm{mg}$ $\mathrm{L}^{-1}$ respectively demonstrated best for greatest callus induction $(1.38$ and $1.65 \mathrm{~g})$ in clone NIA-2011, trailed by BL4(0.95g) through the application of 2,4-D (1.0 $\mathrm{mg} \mathrm{L}^{-}$ $\left.{ }^{1}\right)$ Increase and decrease in the concentration of 2, 4-D adversely influenced the ratio of callus development and growth. At the higher concentration medium (4.0 $\left.\mathrm{mgL}^{-1} 2,4-\mathrm{D}\right)$, the ratio of callus formation decreased in clones NIA-2010 and NIA-
2011 (Table 1 and Figure 1). Comparative results were accounted for by Shahid et al. [21]. In addition, [22] had additionally reported that the callus induction capacity in sugarcane is genotype dependent.

Types of callus (A) regenerable and (B) non-regenerable

Study of callus type is also important for the identification of various responses of callus tissues. Two types of callus were discovered (and) signified in the study, as re-generable callus Type-A and non-regenerable callus 
Type-B. The regenerable callus were distinguished and perceived as dry nodular compact and light yellowish in color as wild, however, B type callus was watery, translucent and non-nodular in shape (Figures 1 and 2). Whereas, Type A (dry nodular and compact callus) was found in clones of BL4, though, NIA-2010 andNIA 2011 had smooth conservative callus denoted as Type A and B (Table 1). The outcomes are upheld by Seema et al. [8].
Who reported three clones of_sugarcane with the utilization of 2,4-D (2.0 $\left.\mathrm{mg} \mathrm{L}^{-1}\right)$ dry nodular callus in BL4. According to the study by Gunderson et al. [23] the embryogenic sort A callus and nonembryogenic sort B callus was seen on the premise of callus external. It was observed that sort B callus of sugarcane did not show the same characteristics, rather, its development generously decreased.

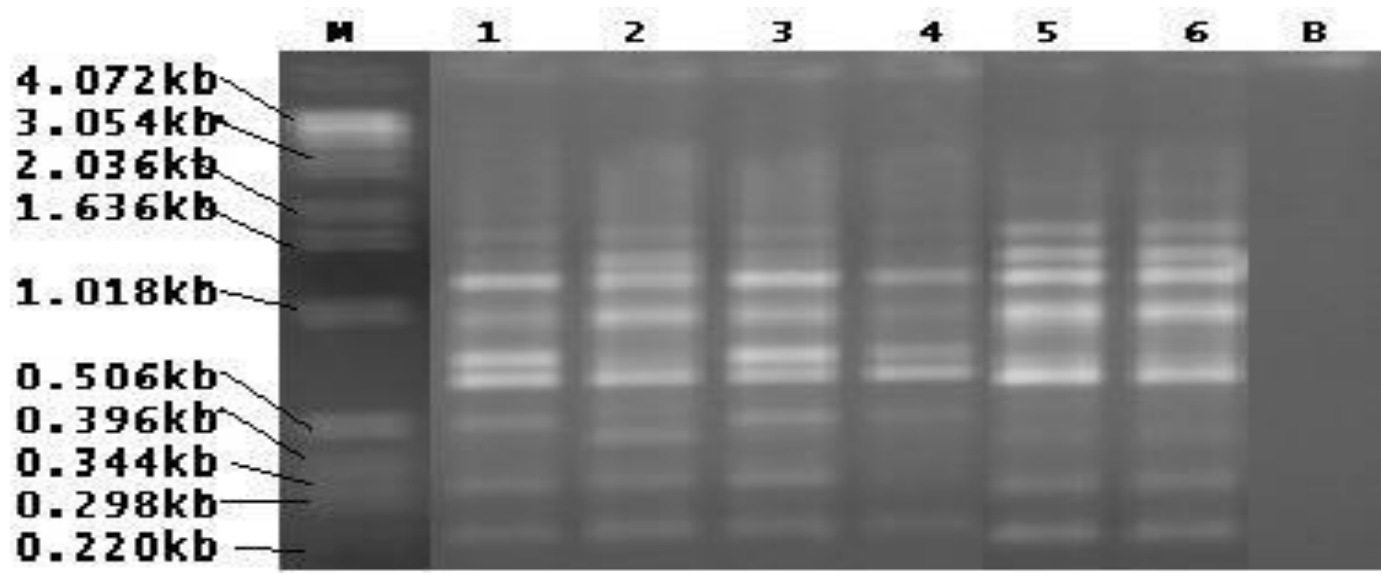

Figure 1. RAPD-PCR with primer A-3, M=DNA marker, $1=$ NIA 2010, $2=2010 S C$, 3=NIA2011P, 4=NIA-2011SC, 5=BL4P, 6=BL4SC, B=Control

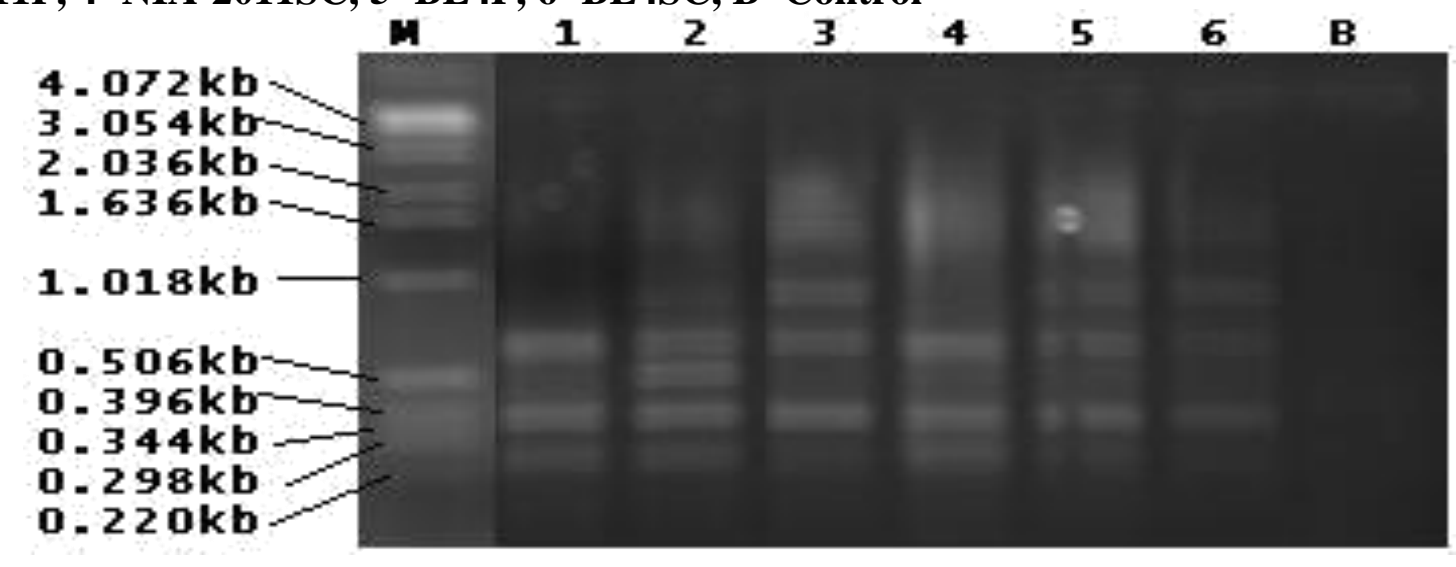

Figure 2. RAPD-PCR with primer A-02, $M=D N A$ marker, 1=2010P 2=2010SC, 3=2011P 4=2011SC, 5=BL4P, 6=BL4SC, B=Control

Weight of callus proliferation / bottle (g)

The proliferation reaction callus varied regarding sub Culturing. It decreased significantly with an increase in growth regulator concentration. Maximum proliferation of callus $(2.45 \mathrm{~g}$ ) was observed in NIA-2011 somaclone with medium containing $1.0 \mathrm{mg} \mathrm{L}^{-1}$ 2, 4-D. However, the 
minimum value $(0.33 \mathrm{~g})$ was observed in same somaclone using concentration of 4.0 $\mathrm{mg} \mathrm{L}^{-1}$ 2, 4-D (Table 5 and Figure 3). These outcomes are trailed by Dibax and Bomfim [24] whose perceptions portrayed the embryogenic masses proliferation on MS culture medium with 2, 4-D, the diminishment of 2, 4-Dconcentration to (2.0 $\mathrm{mg} \mathrm{L}^{-1}$ ) Effectively double the number of embryogenic masses in every subculture.

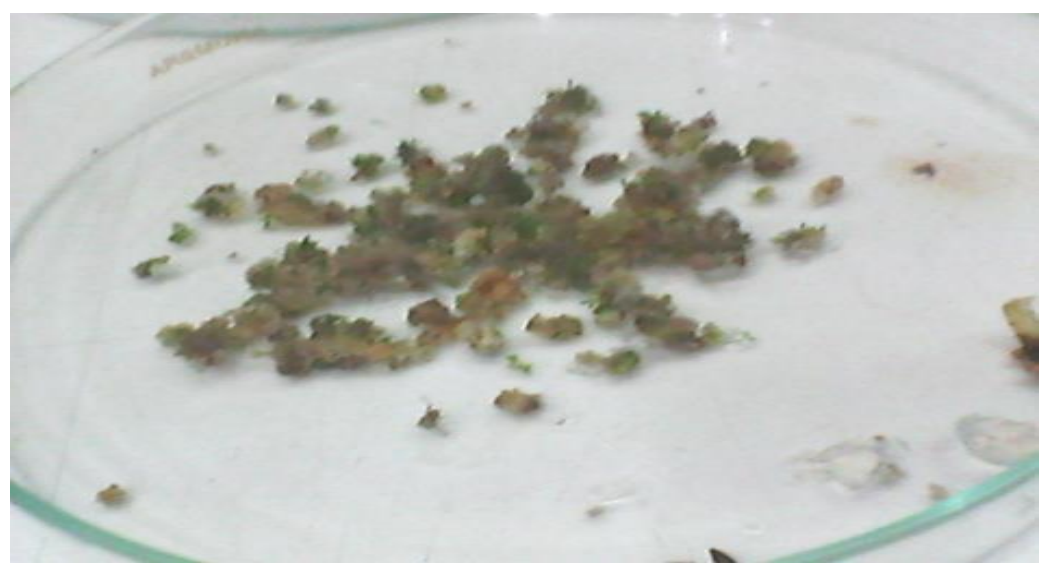

Figure 3. Maximum proliferation of callus (2.45g) was seen in NIA-2011 somaclone with medium containing $1.0 \mathrm{mg} \mathrm{L}^{-1} 2,4-\mathrm{D}$. However, the least $(0.33 \mathrm{~g})$ was observed found in same somaclone using application of $4.0 \mathrm{mg} \mathrm{L}^{-1} 2,4-\mathrm{D}$

\section{Number of plants/bottle}

Regeneration potential was specific and a genotype dependent phenomenon. The plantlets as affected by different growth regulators containing higher number of plantlets (33.400) in NIA-10 somaclone on callus derive from 2, 4-D $\left(2.0 \mathrm{mg} \mathrm{L}^{-1}\right)$, followed by, 31.800 plantlets through the application of 2, 4-D $\left(3.0 \mathrm{mg} \mathrm{L}^{-1}\right)$ in the same clone. Minimum numbers of plantlets were observed on callus derived from2, 4-D in all three clones namely; BL4, NIA-2010 and NIA-2011 (Table 6 and Figure 4). These information affirmed the outcomes reported in Primula ssp. [25] Oryza sativa [26].

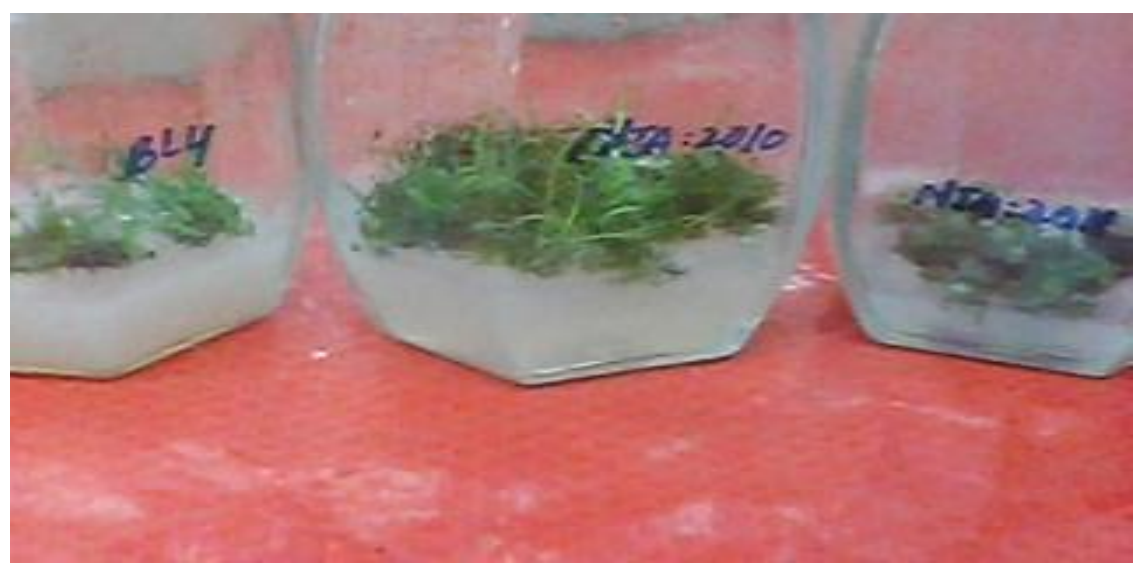

Figure 4. Plantlets were observed on callus derived from 2, 4-D in all three clones namely; BL4, NIA-2010 and NIA-2011 
Size of shoots length plant ${ }^{-1}(c)$

A significant decrease in size of shoot length was observed with an increase in growth regulator concentration. Stretched shoots $(9.20 \mathrm{~cm})$ were observed in BL4 somaclone with $1.0 \mathrm{mg} \mathrm{L}^{-1} 2$, 4-D concentration used. Maximum shoot elongation was also noted in NIA-2010 somaclone with the application of 2, 4-D (1.0, 2.0 and $\left.3.0 \mathrm{mg} \mathrm{L}^{-1}\right)$. The clones were non-significant However, minimum shoot length $(1.06 \mathrm{~cm})$ was noted in NIA-11 somaclone on callus derived from $0.5 \mathrm{mg} \mathrm{L}^{-1}$ 2, 4-D (Table 3 and Figure 4). Comparable results were likewise by Raza $e t$ al. [16] Gunderson et al. [23] in sugarcane.

\section{Number of Chlorophyll mutant / bottle}

Regeneration of albino and viridis plantlets displayed the presence of chlorophyll changes in-vitro plantlets. The chlorophyll mutant under the influence of growth regulator concentrations showed maximum numbers of chlorophyll mutants (6.40) when NIA-10 somaclone was grown on callus derived from $1.0 \mathrm{mg} \mathrm{L}^{-1} 2,4-\mathrm{D}$. Minimum chlorophyll mutant was recorded in NIA2011somaclone through application of 0.5 $\mathrm{mg} \mathrm{L}^{-1}$ 2, 4-D (1.00) (Table 8 and Figure 4). A chlorophyll lacking phenotype can be responsible for passive transformations [3, 27] additionally reported high genetic similarity among sugarcane varieties using RAPD marker.

\section{Number of roots plant ${ }^{-1}$}

The number of roots affected by various concentrations of IBA recorded higher number of primary and secondary roots (13.40) in NIA-2010 somaclone when1.0 $\mathrm{mgL}^{-1} \mathrm{IBA}+20 \%$ sugar was applied and trailed by BL4 somaclone (13.00) provided with $2.0 \mathrm{mg} \mathrm{L} \mathrm{L}^{-1} \mathrm{IBA}+2 \%$ sugar. The increased IBA concentration $\left(3.0 \mathrm{mg} \mathrm{L}^{-1}\right.$ IBA+ $20 \%$ sugar) significantly decreased number of primary rootlets of BL4, NIA2010, and NIA-2011 somaclone (Table 4).
Analysis of variance of number of root plant $^{-1}$ regenerated from various concentrations of IBA with different varieties. [7] Shoed or depicted that utilization of IBA with $6 \%$ sucrose in growth medium incited fiery root improvement. The plantlets with all around created shoots and roots were transferred to jiffy pots having sterilized perlite. After acclimatization the plantlets were initially transferred to the pots for hardening and later on in the field. Highest number of bands was obtained with Primer A-02, while the lowest numbers were obtained with primers B-10 and B-08 (Figures 1 and 2). Some specific bands were also identified, thus, reflecting the RAPDs application for the identification of sugarcane mutants. Results revealed that somaclone 2010 and NIA-2011 somaclone contains a specific band of $451 \mathrm{bp}$ amplified with primer A-2. In the relationship between sugarcane somaclones and parent, the highest similarity was obtained between BL4P and BL4SC (96\%), while minimum similarity was found between NIA-2011 and NIA 2010SC (69\%).

Molecular markers have turned out to be efficient tools in the characterization and estimation of genetic diversity within the species and population [18] RAPD markers have turned out to be a solid marker framework for genetic fingerprinting and furthermore, for identifying genetic diversity $[19,28]$ reported that some RAPD bands were acquired in sugarcane families, showing that RAPD bands could effectively be utilized as genetic markers. While RAPD-PCR fingerprints have been generally utilized in diverse studies, the utility of RAPD- based bands as markers is confounded as they may not be locusspecific [29] and products of various sequences or concentrations can co-migrate 
with other amplification products $[3,30]$.

Polymorphism in repetitive DNA sequences has habitually been seen amid plant propagation by tissue culture [31] and experiences a bigger number of changes than the coding sequences. In vitro stress may incite changes at particular sites, for example, tedious DNA, in this way activating transposable components. High rate of molecular polymorphism was observed in tissue culture in the era of new variability by Shahid et al. [21] that developed a technique to obtain intact somatic metaphase sugarcane cells. Together, these observations recommended either that a few genotypes are more susceptible to somaclonal variation, or that the in vitro unsteadiness is really a result of a genotype versus culture medium interaction.

Table 11. Effect of different concentration of indolebutric acid (IBA) + sugar on root induction

\begin{tabular}{|c|c|c|c|c|}
\hline Concentrations of IBA $\mathrm{mgL}^{-1}$ & BL4 & NIA-2010 & NIA-2011 & Mean \\
\hline 0.5 & $6.40^{\mathrm{c}}$ & $5.00^{\mathrm{cd}}$ & $3.80^{\mathrm{d}}$ & $5.067^{\mathrm{b}}$ \\
\hline 1.0 & $12.00^{\mathrm{a}}$ & $13.40^{\mathrm{a}}$ & $8.60^{\mathrm{b}}$ & $11.33^{\mathrm{a}}$ \\
\hline 2.0 & $13.00^{\mathrm{a}}$ & $12.40^{\mathrm{a}}$ & $9.60^{\mathrm{b}}$ & $11.66^{\mathrm{a}}$ \\
\hline 3.0 & $5.80^{\mathrm{c}}$ & $6.20^{\mathrm{c}}$ & $6.00^{c}$ & $6.00^{\mathrm{b}}$ \\
\hline Mean & $9.3^{\mathrm{b}}$ & $9.15^{\mathrm{a}}$ & $7.00^{\mathrm{c}}$ & \\
\hline
\end{tabular}

\section{Conclusion}

Callus culture of three somaclones NIA2011, NIA-2010 and BL4 produced genetic variability in the clone. During the research study, dry nodular and compact callus were found in two clones BL4 and NIA-2010 somaclones, while the smooth compact callus recognized type $\mathrm{A}$ and $\mathrm{B}$ callus in NIA-2011. Maximum callus and plant regeneration were observed with used 1.0 and $2.0 \mathrm{mg} \mathrm{L}^{-1}$. 2, 4-D. However, maximum proliferation of callus was also observed in same concentration of 2, 4-D, while increased concentration of IBA + sugar decreased primary and secondary roots. The NIA-2010, somaclone produced vigorous plants during the hardening process in greenhouse as well as, has outstanding performance in field during acclimatization process.

\section{Authors' contributions}

Conceived and designed the experiments: $M$ Naz, Performed the Experiments: M Naz, Analyzed the Data: M Naz, Contributed reagents / materials/ analysis tools: $\mathrm{M} \mathrm{Naz}$, Wrote the paper: M Naz \& F Hayat.

\section{References}

1. Zamir, Roshan, Syed SAH, Mulgund TS \& Kummar SV (2011). Efficient in vitro regeneration of sugarcane (Saccharumoffici L.) from bud explants. Res Bio 8(3): 3095-3099

2. Yadav S \& Ahmad A (2013). Standardisation of callus culture techniques for efficient sugarcane micropropagation. Cibtech J Bio-Protoc 2(2): 29-32.

3. Nasir IA, Jahangir G, Qamar Z, Rahman Z \& Tayyab H (2011). Maintaining three generation potential of sugarcane callus for longer span. Pak J Agric Rese 6(1): 113-119.

4. Reis RS, Vale Ede M, Heringer AS, Santa-Catarina C, Silveira V. 2016. Putrescine induces somatic embryo development and proteomic changes in embryogenic callus of sugarcane. $\mathbf{J}$ Proteomics. 1(130):170-179

5. FAO (2012). http://faostat.fao.org/ 
6. Ali A, Naz S \& Siddique A (2008). Somatic embryogenesis and plantlet formation in different varieties of sugarcane (Saccharumoffici L.) HSF-243 and HSF-245. Sarhad J Agric 24(4): 593598.

7. Khatri A, Khan IA, Javed MA, Siddiqui MA, Khan MKR, Khanzada MH, Dahar NA \& Khan R (2002). Studies on callusing and regeneration potential of indigenous and exotic sugarcane clones. Asian J Plant Sci 1(1): 41-43.

8. Seema N, Oad FC, Khan IA, Tunio SM, Siddiqui A, Yasmin S \& Bibi S (2011). Influence of phytohormone on the organogenesis of sugarcane. Pak J Bot 43(3): 1531-1534.

9. Sobahkumari VP (2012). Assessment of somaclonal variation in sugarcane. $J$ Afric Biotechnol 11(87): 15303-15309.

10. Tahir SM, Victor K \& Abdulkadir S (2011). The Effect of 2, 4Dichlorophenoxy acetic acid concentrations on callus induction in sugarcane (Saccharumoffici L). J Appl Sci 19(2): 213-217.

11. Alcantara BG, Filho JCB \& Edelclaiton D (2012). Plant regeneration and histological study of the somatic embryogenesis of sugarcane (Saccharum spp.) cultivars RB855156 and RB72454. $J$ Marin 36(1): 63-72.

12. Khan IA, Dahot MU, Seema N, Yasmin S, Bibi S, Raza S \& Khatri A (2009). Genetic variability in sugarcane plantlets developed through in vitro mutagenesis. Pak J Bot 4(1): 153-166.

13. Karim M, Alam ZR, Baksha R, Paul SK, Hossain MAB \& Rahman MM (2002). In vitro clonal propagation of sugarcane (Saccharum office L.) variety. Pak J Biol Sci 2(5): 659-661.

14. Larkin RJ \& Scowcroft WR (1981). Somaclonal variation a novel source of variability from cell cultures for plant improvement. Theor Appl Genet 60(2): 19

15. Kaur A \& Gosal SS (2009). Desiccation of callus enhances somatic embryogenesis and subsequent shoot regeneration in sugarcane. Indian $J$ Biotechnol 8(3): 332-334.

16. Raza G, Kazim Ali, Mukhtar Z, Mansoor S, Arshad M \& Asad S (2010). The response of sugarcane (Saccharumoffici L) genotypes to callus induction, regeneration and different concentrations of the selective agent (geneticin 418) Afric J Biotechnol 9(51): 8739-8747.

17. Smiullah, Farooq Ahmad Khan, Abdullah, Rameez I, Muzaffar MR, Rasheda A, Ghazanfar H, Ambreen, Rana HM \& Usman I (2013). Callogenesis and Organogensis studies in some accessions of Saccharumoffici L. J Agric Sci 5(4): 916-9752.

18. Lal M, Singh RK, Srivastava S, Singh N, Singh SP \& Sharma ML (2008). RAPD marker based analysis of micropropagated plantlets of sugarcane for early evaluation of genetic fidelity. Sugar Tech 10(1): 99-103.

19. Murashige, T; Skoog, F (1962). "A Revised Medium for Rapid Growth and Bio Assays with Tobacco Tissue Cultures". Physiologia Plantarum. 15 (3): 473-497

20. Jain R, Srivastava S, Singh J \& Gupta PS (2005). Assessment of genetic purity of micropropagated plants of sugarcane by isozyme and RAPD analysis. Sugar Tech 7(2): 15-19.

21. Shahid MTH, Khan FA, Saeed A \& Fareed I (2011). Variability of red rotresistant somaclones of sugarcane genotype S97US297 assessed by RAPD and SSR. Genet Mol Res 10 (3): 18311849.

22. Haq I \& Memon S (2012). Efficient plant regeneration through 
somaticembryogenesis in sugarcane (Saccharum office L.) cultivar CPF-237. Afr J Biotechnol 11(15): 3704-3708.

23. Gunderson $\mathrm{CH}$, Errabil T, Abrini J, Idaomar M, Chibi F \& Senhaji NS (2005). Effect of genotype on callus induction and plant regeneration from leaf explants of sugarcane (Saccharum spp.). Afr J Biotechnol 4(11): 12501255.

24. Dibax R \& Bomfim, Alcântara (2011). Plant regeneration of sugarcane cv. RB931003 and RB98710 from somatic embryos and acclimatization. $J$ Biotechnol Biodivers 2(3): 32-37.

25. Schween G \& Schwenkel HG (2003). Effect of genotypeon callus induction, shoot regeneration and phenotypicstability of regeneratedplants in greenhouse of Primulassp. Plant Cell Tissue Organ Cult 7(2): 53-61.

26. Hoque ME \& Mansfield JW (2004). Effect of genotype andexplant age on callus induction and subsequent plantregeneration from root-derived callus of indica rice genotypes. Plant Cell Tissue Organ Cult 7(8): 217-223.
27. Heringer AS, Barroso T, Macedo AF, Santa-Catarina C, Souza GH, Floh EI, de Souza-Filho GA \& Silveira V (2015). Label-Free Quantitative Proteomics of Embryogenic and Non-Embryogenic Callus during Sugarcane Somatic Embryogenesis. PLoS One Jun 2 10(6):

28. Huckett BI \& Botha FC (1995). Stability and potential use of RAPD markers in a sugarcane genealogy. Euphytica 86(5): 117-125.

29. Besse P, Taylor G, Carroll B, Berding N, Burner DM \& McIntyre CL (1998). Assessing genetic diversity in a sugarcane germplasm collection using an automated AFLP analysis. Genetica 104(2): 143-153.

30. Pillay M \& Kenny ST (1995). Anomalies in direct pair-wise comparisons of RAPD fragments for genetic analysis. Biotechnique 19(5): 694-698.

31. Ahmed AZ \& Khaled KAM (2009). Detection of Genetic Similarity of Sugarcane Genotypes. Gene Conserve Aca J 3(1): 686-697. 